\title{
GDP AND LENDING BEHAVIOUR: EMPIRICAL EVIDENCE FOR BALTIC STATES ECONOMIES
}

\author{
Ģirts Braslinš̌ ${ }^{1}$, Aleksis Orlovs² ${ }^{2}$ Ieva Braukša ${ }^{3}$, Aldis Bulis ${ }^{4}$ \\ University of Latvia (Latvia)
}

\begin{abstract}
Sustainable economic development is based on the favourable and stable business environment that promotes competitiveness of companies. Commercial banks facilitate the capital flow from the less efficient sectors of the economy and businesses to more competitive industries and enterprises. The purpose of the research is to analyze the dynamics of the Baltic States' GDPs during years 2005-2010 and to test the GDP correlation with the loans issued by domestic commercial banks to the businesses. The key results of the analysis provide evidence about the mutual relations between the leading and influencing factors in GDP and issued loans and serve as a basis for developing proposals on fostering the recovery of Baltic States' economies. The Granger test analysis performed for the aggregate GDP and lending, as well as for six industries, provides controversial results and indicates that output in some industries has mutual relationship with the availability of financial resources, however the business sector development leads to the increase of credit granting thus ensuring the development of the sector. The methods applied in the research comprise the systematic, logical and comparative analysis, analysis of statistical data, expert method and generalization, as well as the econometric Granger causality test method.
\end{abstract}

KEY WORDS: Loans, GDP, Granger causality test, loans and output.

JEL CODES: E32, G10.

\section{Introduction and research objectives}

Sustainable economic development is usually based on the favourable and stable business environment that promotes competitiveness of companies. Commercial banks have a significant role in the development of a country's economy. Commercial banks facilitate and manage the capital flows from the less efficient sectors of the economy to more competitive industries and firms. Additionally, credits have another significant role in the economy of each country, because they substantially increase the purchasing power of consumers

1 Ģirts Brasliņš - PhD student, Faculty of Economics and Management, University of Latvia. Scientific interest: credit risk management

E-mail: girts.braslins@ge.com

Tel.: +37129403057

2 Aleksis Orlovs - PhD student, Faculty of Economics and Management, University of Latvia. Scientific interest: clusters management

E-mail: aleksis.orlovs@fms.lv

Tel.: +37129287289

3 Ieva Braukša - PhD student, Faculty of Economics and Management, University of Latvia, Scientific interest: regional economics

E-mail: ieva.brauksa@lanet.lv

Tel.: +37126730110

4 Aldis Bulis - PhD student, Faculty of Economics and Management, University of Latvia, Scientific interest: logistics and transportation

E-mail: aldis.bulis@balticvisiongroup.org

Tel.: +37125934522 
and industries, leading to the GDP growth. Without availability of additional financial resources the growth of economy becomes challenging and therefore credits have the key influence on it (Romanova, 2006).

In the period from the beginning of the $21^{\text {st }}$ century till the economic downturn of 2009 Baltic countries' GDPs grew faster than those of other Central and East European (CEE) countries and in Europe could only be matched by Iceland and Spain. In the period from 2000 to 2007 the volume of loans including the loans from foreign creditors increased in average by 20 percent over the previous year. As a result, for example, the total debt of Latvia reached $116 \%$ of GDP in 2007, compared to $35 \%$ of GDP in year 2000 . The debt was still low compared to the average level in the euro area - $135 \%$, however, it was above the level of most CEE countries (Erbenova, 2011). The Baltic States, like many other countries in the CEE region, have experienced substantial capital inflows in the years preceding the economic downturn. In countries with floating exchange rates (Czech Republic, Poland, Romania, Slovak Republic and Ukraine), monetary policy was strengthened by allowing exchange rates to fluctuate. However, in countries with pegged exchange rates (Bulgaria, Estonia, Lithuania and Latvia) capital inflows determined lower interest rates and significant acceleration in credit growth. In many of these countries, including Latvia, Lithuania and Estonia, most of the loans were granted in the Euro currency, due to the lower rates (Brunner, 2006).

Excessive credit granting (especially as mortgages), during the economic development period (2005-2007) lead to increased internal demand that was followed by upward pressure to prices and resulted in overheating of economics. On the other hand, during the economic recession period amounts of granted loans decreased. The problem addressed in this paper is the question which is the leading factor - GDP growth and development of real economy or availability of loans.

The purpose of the research is to investigate how lending responds to monetary policy and GDP shocks in the Baltic States. Therefore the object of the research is GDP and loans in the Baltic States. The authors draw a hypothesis that faster development of an industry means the availability of more credit resources to the particular industry.

The effect of financial development on the economic growth has been studied in various respects in recent years, providing controversial results, which the authors will analyze in the next chapter. European research, in contrast to recent US findings, suggests that a change in the loan growth has a positive and statistically significant effect on GDP. Researchers in US found no compelling evidence for a strong causal relationship between credit supply and real output. The authors will consider the aggregate level to achieve the overall understanding about the connection between loans and GDP. Aggregated indicators have been chosen as they will be used for further and more detailed analysis of GDP-loan relationship. The key results of the analysis provide evidence about the mutual relations between the leading and influencing factors in GDP shocks and loans issued by banks.

To research the authors' hypothesis several items are defined as the goals of this study. First goal is to find out the evidence about the leading and influencing factors in GDP and issued loans mutual relations. Second goal is to test the correlation between the development pace and its access to financial resources (leverage) in industries level and understand this interaction from econometrical perspective.

To achieve purpose of the study, 4 different tasks are defined:

- analyze the dynamics of Baltic States' GDPs and loan indices during the years 2005-2010;

- test the GDP correlation with domestic commercial banks issued loans to the businesses;

- perform the Granger causality test between the growth rates and leverage dynamics of several industries over the period of 2005-2010;

- build econometrical models which provides the impression about the possible behavior of loan and GDP interaction.

The methods of the research are systematical, logical and comparative analysis, analysis of statistical data (correlogram analysis), expert method and generalization as well as econometric method of Granger causality test. 


\section{Literature review and methods}

Most notable papers related to the effect of financial development on economic growth are controversial. Joseph Schumpeter (1991) argued that financial intermediaries play a pivotal role in economic development because they choose which firms get to use society's saving. According to his view, the financial intermediary sector alters the path of economic progress by affecting the allocation of savings and not necessarily by altering the rate of savings. Thus, the Schumpeterian view of finance and development highlights the impact of financial intermediaries on productivity growth and technological change.

Driscoll (2004) discovered that there is a long tradition in the literature on monetary policy, beginning with Brunner and Meltzer (1963) and revived more recently by Bernanke (1983) and many others, that banks may play a special role in the propagation of economic fluctuations. The first is the reverse causality or endogeneity problem: one must determine that correlations between output and money are due to output responding to money and not money demand to expectations of future output. Discroll points out that the positive correlation between output and lending is statistically stronger for construction and investment loans and on the microeconomic level the impact of a change in bank lending is the most severe on small firms (Gertler and Gilchrist, 1994). His research concludes that state-specific money demand shocks have economically and statistically significant effects on the quantity of loans made by banks in that state. After using those shocks as instruments, he found a slight evidence against the contention that shocks to the supply of bank loans raise output. These results are robust to changes in the sample size and choice of a cross-sectional unit. His second finding adds to the negative results found at the aggregate level by Miron et al. (1994), Oliner and Rudebusch (1996) and others that the lending channel has little or ambiguous macroeconomic impact.

Gambacorta and Mistrulli (2005) investigated the existence of cross-sectional differences in the response of lending to monetary policy and GDP shocks owing to a different degree of bank capitalization. They indicate that all theories, which explain how bank capital could influence the propagation of economic shocks, suggest the existence of market imperfections that modify the standard results of the Modigliani and Miller theorem. Broadly speaking, if capital markets were perfect, a bank would always be able to raise funds (debt or equity) in order to finance lending opportunities and its level of capital would have no role (Gambacorta and Mistrulli, 2005).

Tecles and Tabak (2008) estimated the empirical relationship between credit and GDP using a Vector Error Correction model applied to Brazilian data. The study of the effect of GDP on demand for credit was carried by the assumption that better economic conditions increase the consumer and investor optimism. With higher expectations on future income, they tend to smooth consumption by increasing borrowing. Their findings indicate a significant impact of credit supply on future income, which corroborates the credit view hypothesis that financial development has an important role in economic growth. Also, the inverse direction causality is verified. Expectations of higher productivity, measured as future GDP, imply higher individual income prediction and, consequently, a larger demand for credit. Both results highlight the importance of monitoring the aggregate economic activity and the financial sector. The association between credit booms and financial instability, with the consequent depreciation of assets quality and bank crisis supports financial control to assure the output of economy (Tecles and Tabak, 2008).

Shan and Jianhong (2006), also using the Vector Auto Regression (VAR) approach, examined the impact of financial development on the economic growth in the People's Republic of China (China). They found that financial development comes as the second force (after the contribution from labour input) in leading the economic growth in China. Their study has supported the view in the literature that financial development and economic growth exhibit a two-way causality and hence is against the so-called "finance-led growth" hypothesis. They used the VAR techniques of innovation accounting or variance decomposition and impulse response function analysis, including the Granger causality test, to provide a quantitative assessment of 
the relationship between the financial development and GDP growth in China. Financial development was found to be the second force in China (after the contribution from labour) affecting economic growth and the swift reform, and the change in the Chinese financial system has brought about significant credit resources to the economy and hence has contributed to GDP growth in China. However, the authors also found that the strong economic growth of the last 20 years has had a significant impact on financial development by providing a solid credit base (through the rising personal income and private and public resources) in China. This indicates a two-way causality between finance and growth in the context of the so-called "financeled growth" debate. Labour input is the most important force in leading the economic growth in China. From a different methodological perspective, the results of Shan and Jianhong's (2006) study provided the evidence that the hypothesis suggesting that financial development "leads" economic growth is not generally supported by time-series analysis, at least not from the experience of China.

Beck, Levine and Loayza (2000) evaluated the empirical relation between the level of financial intermediary development and economic growth. To clarify the relation between financial intermediation and economic performance, they empirically assess the impact of financial intermediaries on private savings rates, capital accumulation, productivity growth, and overall economic growth. They find that financial intermediaries exert a large and positive impact on total factor productivity growth, which feeds through to the overall GDP growth. The long-run links between financial intermediary development and both physical capital growth and private savings rates are tenuous. They find an economically large and statistically significant relation between financial intermediary development and both real per capita GDP growth and total factor productivity growth. Their specification tests indicate that the robust, positive relation between financial development and both growth and productivity growth are not due to simultaneity bias or countryspecific effects. Their results, however, indicate an ambiguous relation between financial intermediary development and both physical capital growth and private savings rates. These results support the view that better functioning financial intermediaries improve resource allocation and accelerate total factor productivity growth with positive repercussions for long-run economic growth.

IMF report prepared by Favara (2003) re-examines the empirical relationship between financial development and economic growth. It presents evidence on cross-section and panel data using an updated dataset, a variety of econometric methods, and two standard measures of financial development: the level of liquid liabilities of the banking system and the amount of credit issued to the private sector by banks and other financial institutions. Favara identified two sets of findings. First, in contrast with the recent evidence of Levine, Loayza and Beck (2000), cross-section and panel data instrumental variables regressions revealed that the relationship between financial development and economic growth is weak. Second, he founded his evidence on nonlinearities in the data, suggesting that finance matters for growth only at intermediate levels of financial development. Moreover, when he used a procedure appropriately designed to estimate long-run relationships in a panel with heterogeneous slope coefficients, he did not find clear indications that finance spurs economic growth. Instead, for some specifications, the relationship was puzzlingly negative.

The European Central Bank (ECB) (2010), when evaluating the impact of credit growth on output, in its paper indicates that there are a number of issues that need to be addressed. One of the most pertinent issues concerns the endogeneity, or reverse causality, problem, since one cannot distinguish whether loan supply affects output or, vice versa, if the demand for (and supply of) loans is determined by future expected output. ECB found, that in the euro area changes in the supply of credit, both in terms of volumes and in terms of credit standards applied on loans to enterprises have significant effects on real economic activity. In other words, a change in loan growth has a positive and statistically significant effect on GDP. But it cannot be taken for granted that such changes in credit supply in turn have significant effects on real economic activity. Indeed, for the US neither Driscoll (2004) nor Ashcraft (2006) found compelling evidence for a strong causal relationship between credit supply and real output. But contrary to the US experience, the ECB document 
states that changes in credit supply also exert a non-negligible impact on real economic activity in the euro area. The difference between the ECB results for the euro area and the US-based studies probably stems primarily from the greater dependence of the private sector on the bank credit in the euro area.

\section{Results of empirical analysis}

\subsection{Comparative analysis}

When comparing the annual credit index, which is calculated as the volume of granted loans in the current year versus the volume of the granted loans in the previous year, with the annual GDP volume indices, it can be observed that both indices have similar trends till year 2008, except Latvia, where already in 2007 the GDP indices was below $100 \%$. In all other cases, during the time period from year 2005 till year 2008 both indices were above $100 \%$, which means that the volume of the granted loans and GDP rose year over year.

Starting from year 2008 the situation changed - in 2009, the annual GDP indices was $82 \%$ in Latvia, $85 \%$ in Lithuania and Estonia, which means that GDP had decreased by 15-18\%, while the annual indices of loans was $93 \%$ in Latvia, $91 \%$ in Lithuania and $95 \%$ in Estonia, which means that commercial banks had stopped granting loans (Fig.1, 2, 3). For the following year - 2010, both indices showed the opposite trend (except in Latvia) - GDP indices was above $100 \%$ level which means that the economy had started to recover, but the volume of granted loans continued to decrease as credit indices were below $100 \%$ level. As the authors observed in all three Baltic countries, the GDP decrease actually stopped in 2010 and economies started to grow. At the same period (2010) crediting volume continued to decrease and in comparison with the previous year credit volumes dropped from $9 \%$ to $6 \%$ compared to the level in the previous year. GDP had already moved to the next level of the business cycle, but crediting still stayed in the previous one. The obtained data indicate that there is a relationship between the changes in GDP and the volume of granted loans and the leading factor between these two variables is GDP as the changes in the volume of granted loans follow the fluctuation of GDP.

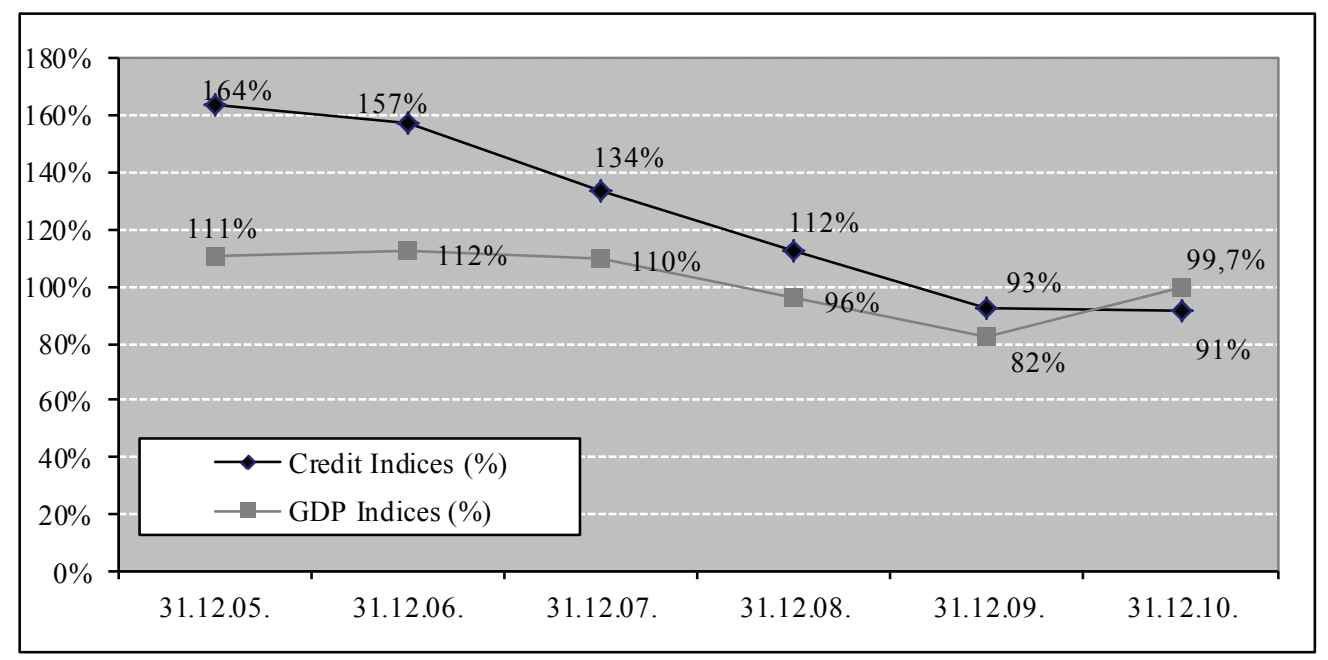

Figure 1. Annual Credit Indices and GDP Indices in Latvia, years 2005-2010

Source: Data from the Financial and Capital Market Commission of Latvia and the Central Statistical Bureau of the Republic of Latvia, authors' calculations 


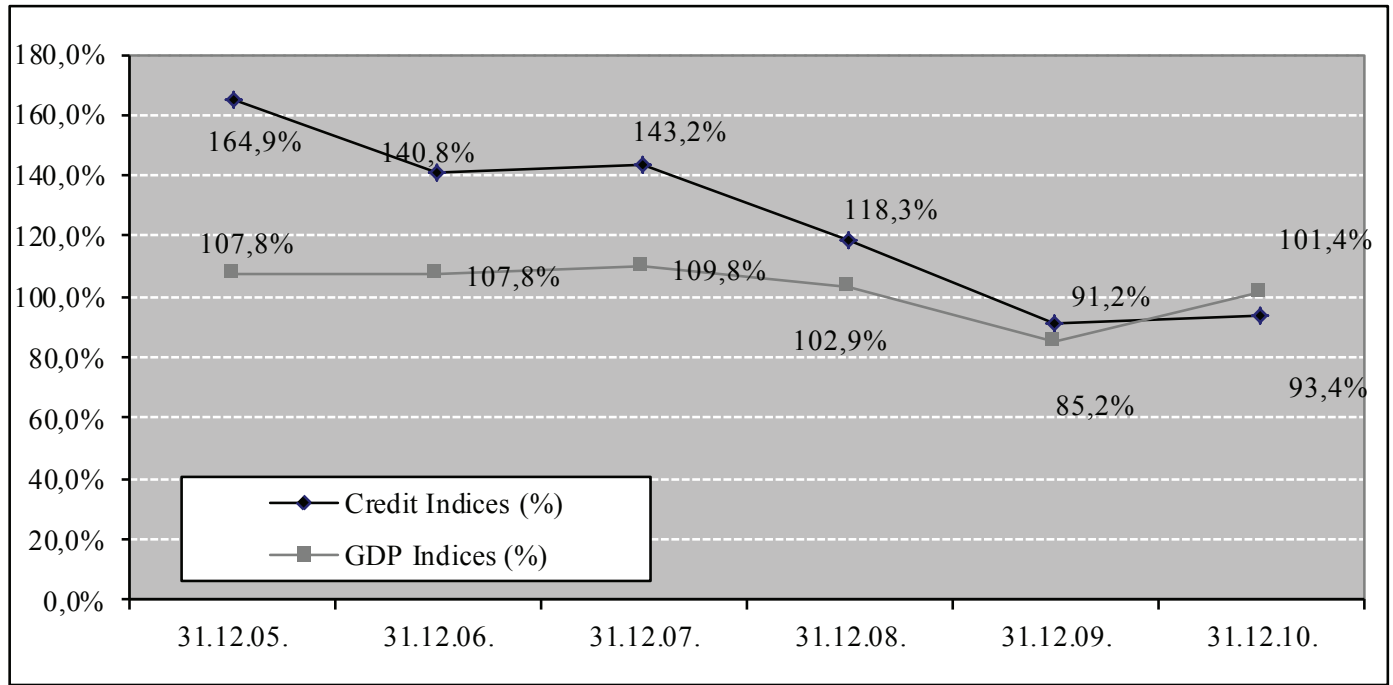

Figure 2. Annual Credit Indices and GDP Indices in Lithuania, years 2005-2010

Source: Data from the Bank of Lithuania and the Statistics Lithuania, authors' calculations

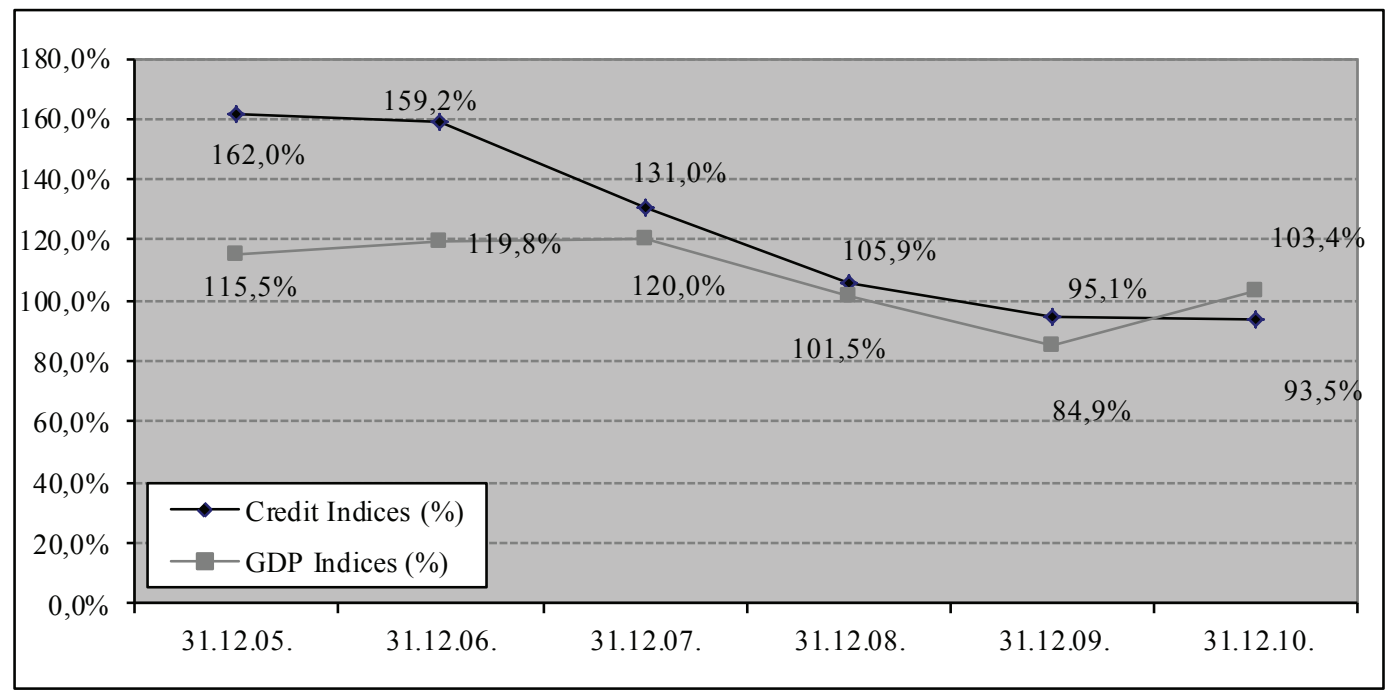

Figure 3. Annual Credit Indices and GDP Indices in Estonia, years 2005-2010

Source: Data from the Bank of Estonia and the Statistics Estonia, authors' calculations

\subsection{Granger test}

The authors, in order to clarify the mutual relations between GDP development and industry lending capability, tested the correlation between the industry development pace and its access to financial resources (leverage). The authors draw a hypothesis that faster development of an industry means the availability of more credit resources to the particular industry.

In order to test the hypothesis the authors performed the Granger causality test analysis between the growth rates and leverage dynamics of 6 industries over the period of 2005-2010. According to the data from the Baltic Statistical Bureaus - Statistics Estonia, Statistics Lithuania and Central Statistical Bureau of Latvia, 6 industries - Agriculture, Manufacturing, Construction, Wholesale/Retail, Operations with Real Estate, Transportations/Logistics contributed on average for more than $60 \%$ of total GDP in year 2010. It can be seen in Table 1 . 
Table 1. Industry output and contribution to GDP in 2010

\begin{tabular}{|c|c|c|c|}
\hline \multirow{2}{*}{ Industry } & \multicolumn{3}{|c|}{ Proportion in GDP, \% } \\
\hline & Latvia & Estonia & Lithuania \\
\hline Agriculture & $4.50 \%$ & $2.87 \%$ & $3.5 \%$ \\
\hline Manufacturing & $13.40 \%$ & $14.31 \%$ & $19.9 \%$ \\
\hline Construction & $5.90 \%$ & $4.98 \%$ & $6.3 \%$ \\
\hline Wholesale and Retail & $16.70 \%$ & $10.39 \%$ & $19.5 \%$ \\
\hline Transportation and Logistics & $12.10 \%$ & $7.72 \%$ & $12.3 \%$ \\
\hline Operations with Real Estate & $8.30 \%$ & $9.50 \%$ & $6.9 \%$ \\
\hline Total: & $61 \%$ & $50 \%$ & $68.4 \%$ \\
\hline
\end{tabular}

Source: Data from the Central Statistical Bureau of the Republic of Latvia, the Statistics Lithuania and Statistics Estonia

The Granger causality test is a statistical method based on prediction - i.e. it estimates if one variable is a signal to predict the value of another variable. This method by its mathematical formulations was introduced by Granger in 1960s and has been widely used in economics since then. To analyse similar concepts to the ones examined in this paper the Granger causality test was used by Sendeniz-Yuncu et al. (2008) and Bebczuk et al. (2010).

In order to statistically determine the causality between loans and output Granger causality test was applied. The quarterly data for period 2005-2010 for GDP and its components and loans by sectors were used. Because of the quarterly dataset, four lags were used so the equations evaluated are as follows:

$$
\begin{aligned}
& y_{t}=\alpha_{0}+\alpha_{1} y_{t-1}+\ldots+\alpha_{4} y_{t-4}+\beta_{1} x_{t-1}+\ldots+\beta_{4} x_{t-4}+\varepsilon_{t} \\
& x_{t}=\alpha_{0}+\alpha_{1} x_{t-1}+\ldots+\alpha_{4} x_{t-4}+\beta_{1} y_{t-1}+\ldots+\beta_{4} y_{t-4}+\varepsilon_{t}
\end{aligned}
$$

where $y_{t}$-output in period $t$;

$x_{t}{ }_{t}-$ loans in period $t$.

Loans are the outstanding loans at the end of the period. Both output and loans are measured in nominal prices. In the further analysis the authors will examine both aggregate numbers (total GDP, total loans) and GDP and loan components split by NACE1 sectors. The Granger causality test presented in Table 2 shows that aggregate GDP and loan data do show causality effects in the Baltic economies, except for Lithuania where it seems that total outstanding loans influence the value of GDP.

Table 2. Results of the Granger test for all three Baltic countries

\begin{tabular}{|l|c|c|c|}
\hline Null Hypothesis: & Latvia & Estonia & Lithuania \\
\hline GDP does not Granger Cause LOAN_TOTAL & 0.392 & 0.7742 & 0.6412 \\
\hline LOAN_TOTAL does not Granger Cause GDP & 0.8982 & 0.1696 & 0.0327 \\
\hline
\end{tabular}

The summary of Granger test results for all three Baltic countries in a more detailed split by sectors can be found in Table 3 provided in the attachment in. There are some interesting results when looking more deeply at particular sectors. With $95 \%$ confidence it can be said that in the wholesale and retail sector loans influence output and vice-versa - output influences the amount of outstanding loans both in Latvia and Estonia. The data for Lithuania for this sector cannot be split and are shown together with the data on transport, logistics and accommodation. Probably that is the reason why no causality effects appear for the wholesale and retail loans and output in Lithuania. In the transport and logistics sector the only causality that can be found is between the loans to transport and logistics sector and total GDP in Latvia. As there is no 
Granger causality between the loans to this sector and output of transport, there is no direct impact, although some indirect impact might exist because of the possibilities to develop some other sectors of economy. No connections between the loans and output in the transport sector are found in Estonia either. In the operations with real estate there is a clear causality by loans to the real estate sector influencing the output of this sector in all Baltic countries, but the authors should note that till 2008 the data for operations with the real sector in Latvia and for the first two quarters of 2005 in Estonia and the whole period in Lithuania also included the data on loans to some additional subsectors like rent and other business activities, that could leave some impact on results, however, as the amount of these extra sectors is small, this impact should not be significant.

For agriculture the authors have not found causality effects which might mean that the increase of loans does not have much influence on agriculture output. That could be explained by seasonal factors and good or bad weather which influence the output regardless the amount of loans outstanding. Moreover, the loans for agriculture could be long term investments that do not yield full payback in one year; consequently the impact of the loans is not so apparent. In Estonia and Lithuania there seems to be the opposite effect as the output in agriculture influences the value of the outstanding loans to this sector.

In manufacturing, though, there are no strong connections observed, the effect is in the opposite direction to the sectors previously mentioned. With $90 \%$ confidence for Latvia and $99 \%$ confidence for Estonia the authors can say that the output in the manufacturing industry influenced the loans for this industry. That might suggest that banks are more eager to credit the already well-established enterprises and lend money for other purposes than further development. This connection in Lithuania is less pronounced.

What concerns construction, in Latvia the authors did not find causality effects in any of the tested directions meaning that in the period of 2005-2010 construction was motivated by other factors than the availability of loans (that could be the internal demand, loans issued for other sectors (e.g. operations with real estate) or some other factors). The authors find the situation in Lithuania and Estonia slightly different as the loans to the construction sector influence the output of this sector.

\subsection{Correlograms and econometric model}

The methods of the second research are systematic, logical and comparative analysis and statistical methods (correlogram analysis, statistical model analysis). Correlogram analysis is a widely used statistical data analysis method for time series and is used for checking the randomness of data. Based on this analysis it is possible to build more precise models which will be used for the further analysis of GDP and loan behaviour. The analysis of the created model supplement performed in previous chapters provides the impression about the possible behaviour of loan and GDP interaction. For deeper analysis more complex models are needed, but this is the first step to estimate the possible relationships between these indicators and their strength.

The quarterly data from years 2005 to 2010 about the outstanding loans and data about the GDP in Latvia, Estonia and Lithuania were used in the statistical analysis. Previous research by the authors (Braslins, Orlovs, Brauksa, 2012) shows that there are some causality effects between the loans issued and the output. This effect is significant (at the level of $95 \%$ probability) in Lithuania, however, at the aggregate level these causalities were not significant in other Baltic countries including Latvia. The research indicated that the strongest influence was observed in such sectors as wholesale and retail, construction and operations with real estate.

The analysis using the Granger causality test revealed some causality between loans and output, therefore authors will test the overall situation and some specific sectors (wholesale/retail, operations with real estate and construction) more deeply to analyze the loan-output relationships. The first step in our analysis is to evaluate the amount of these effects. We looked at the aggregate level to get the overall understanding about the connection between loans and GDP. Those indicators are chosen as they will be used in the further analysis for examining the GDP-loan relationships more carefully. The analysis is based on quarterly data. Correlograms were used to evaluate the effect of auto correlation. First of all, in Figure 4 the authors show 
correlograms for quarterly GDP data for all three Baltic countries. The quarterly effect can be seen in the partial auto correlation table as there are larger spikes for the $1^{\text {st }}$ and then $5^{\text {th }}$ and $9^{\text {th }}$ spike. In general it can be said that the partial correlation with lag 1 has a spike and the values in the autocorrelation graph are slowly decreasing.

Latvia

\begin{tabular}{|c|c|c|c|c|}
\hline \multicolumn{2}{|c|}{ Autocorrelation } & \multicolumn{3}{|c|}{ Partial Correlation } \\
\hline 1 & $\square$ & 1 & & 1 \\
\hline 1 & $\square$ & 1 & 1 & 2 \\
\hline । & $\sqsupset$ & 1 - & I & 3 \\
\hline 1 & & 1 & I & 4 \\
\hline 1 & 1 & $\square$ & I & 5 \\
\hline 1 & 1 & 1 & I & 6 \\
\hline $1 \square$ & 1 & 1 & I & 7 \\
\hline 1 口 & 1 & । & I & 8 \\
\hline$\square$ & 1 & 1 다 & I & 9 \\
\hline$\square$ & 1 & 1 & I & 10 \\
\hline$\square$ & 1 & 1 & I & 11 \\
\hline $1 \square$ & 1 & 1 & I & 12 \\
\hline
\end{tabular}

Estonia

\begin{tabular}{|c|c|c|c|c|c|}
\hline \multicolumn{2}{|c|}{ Autocorrelation } & \multicolumn{4}{|c|}{ Partial Correlation } \\
\hline 1 & $\square$ & 1 & & $\square$ & 1 \\
\hline 1 & $\square$ & 1 & $\square$ & 1 & 2 \\
\hline 1 & י & 1 둥 & & 1 & 3 \\
\hline 1 & $\square$ । & 10 & 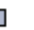 & 1 & 4 \\
\hline 1 & 1 & $\sqsubset$ & & I & 5 \\
\hline 1 & 1 & 10 & & 1 & 6 \\
\hline $1 \square$ & 1 & 1 & & 1 & 7 \\
\hline $1 \square$ & 1 & 1 & 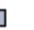 & 1 & 8 \\
\hline 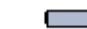 & 1 & 10 & & 1 & 9 \\
\hline$\square$ & 1 & 17 & & 1 & 10 \\
\hline$\square$ & 1 & 1 & & 1 & 11 \\
\hline $1 \sqsubset$ & 1 & 1 & ב & 1 & 12 \\
\hline
\end{tabular}

Lithuania

\begin{tabular}{|c|c|c|c|c|c|}
\hline \multicolumn{2}{|c|}{ Autocorrelation } & \multicolumn{4}{|c|}{ Partial Correlation } \\
\hline I & 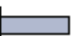 & । & 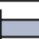 & $\square$ & \\
\hline ' & ए & 1 & & 1 & \\
\hline 1 & إ & I & & I & \\
\hline 1 & $\square$ & 1 & $\square$ & 1 & \\
\hline 1 & $\sqrt{1}$ & $\square$ & & । & \\
\hline 1 - & 1 & 1 & & । & \\
\hline 1 & 1 & 1 & 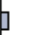 & । & \\
\hline 17 & 1 & 1 & & । & \\
\hline $1 \square$ & 1 & $1 \square$ & & । & \\
\hline ' & I & 15 & & ' & 10 \\
\hline $1 \square$ & I & 1 & & । & 11 \\
\hline $1 \square$ & 1 & 1 & 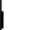 & 1 & 12 \\
\hline
\end{tabular}

Figure 4. Results of correlograms for GDP

Source: data from the Central Statistical Bureau of the Republic of Latvia, the Statistics Estonia and the Statistics Lithuania, authors' calculations

Similar results can also be seen in Figure 5 showing the results for the quarterly data on the total outstanding loans, however the partial correlation graph is much clearer here with a large first spike and decrease in the autocorrelation graph.

So the results of this part of the research make the authors conclude that both GDP and the amount of the outstanding loans depend strongly on their value in the previous quarter because the partial correlation with lag 1 features a spike, while the autocorrelation values are decreasing and the decrease is close to being exponential.

\begin{tabular}{|c|c|c|c|c|}
\hline Autocor & relation & Partial Co & elation & \\
\hline 1 & & 1 & ב & 1 \\
\hline 1 & $\square$ & 1 & 1 & 2 \\
\hline 1 & $\square$ & 1 & 1 & 3 \\
\hline 1 & $\square$ & 1 & 1 & 4 \\
\hline 1 & $\square$ & 15 & 1 & 5 \\
\hline 1 & 口 1 & 1 & 1 & 6 \\
\hline 1 & 1 & 1 & 1 & 7 \\
\hline 1 & 1 & 1 & 1 & 8 \\
\hline 1 & 1 & 10 & 1 & 9 \\
\hline $1 \square$ & 1 & 10 & 1 & 10 \\
\hline $1 \square$ & 1 & 10 & 1 & 11 \\
\hline $1 \square$ & 1 & 1 & 1 & 12 \\
\hline
\end{tabular}

\begin{tabular}{|c|c|c|c|c|}
\hline Autocorr & relation & Partial Co & elation & \\
\hline 1 & & 1 & & 1 \\
\hline 1 & $\square$ & 10 & 1 & 2 \\
\hline 1 & 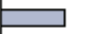 & 1 & 1 & 3 \\
\hline 1 & $\square$ & 10 & 1 & 4 \\
\hline 1 & $\square$ I & 10 & 1 & 5 \\
\hline 1 & 曰 1 & 1 & 1 & 6 \\
\hline 1 & b 1 & 10 & 1 & 7 \\
\hline 10 & 1 & 1 & 1 & 8 \\
\hline 1 다 & 1 & 1 & 1 & 9 \\
\hline $1 \square$ & 1 & 15 & 1 & 10 \\
\hline $1 \square$ & 1 & 1 & 1 & 11 \\
\hline $1 \square$ & 1 & 1 & 1 & 12 \\
\hline
\end{tabular}

\begin{tabular}{|c|c|c|c|c|c|}
\hline \multicolumn{2}{|c|}{ Autocorrelation } & \multicolumn{4}{|c|}{ Partial Correlation } \\
\hline I & & 1 & & $=$ & 1 \\
\hline 1 & $\square$ & & & 1 & 2 \\
\hline 1 & $\square$ & 1 & प & 1 & 3 \\
\hline I & $\square$ & 1 & b & 1 & 4 \\
\hline I & וב & 1 & d & 1 & 5 \\
\hline 1 & 1 & 1 & ] & 1 & 6 \\
\hline 1 & 1 & 1 & 드. & 1 & 7 \\
\hline 1 & 1 & 1 & d & 1 & 8 \\
\hline 1 & 1 & 1 & ㄱ․ & 1 & 9 \\
\hline $1 \sqsubset$ & 1 & 1 & t & 1 & 10 \\
\hline $1 \square$ & 1 & 1 & $d$ & 1 & 11 \\
\hline $1 \square$ & 1 & 1 & I & 1 & 12 \\
\hline
\end{tabular}

Figure 5. Results of correlograms for Loans

Source: data from the Financial and Capital Market Commission of Latvia, the Eesti Pank and the Bank of Lithuania, authors' calculations

Based on the conclusion that the GDP value depends on its value in the previous period, the following model was built by using the least squares and ARMA method: 


\begin{tabular}{|c|c|c|c|c|}
\hline & constant & ln_out $(t-1)$ & $\ln _{-} \operatorname{loan}_{i}(t-1)$ & $R^{2}$ \\
\hline \multicolumn{5}{|l|}{ Latvia: } \\
\hline $\ln$ (output) & 3.8796 & 0.7072 & 0.0338 & $77.3 \%$ \\
\hline$p$ values & 0.017 & 0.001 & 0.780 & \\
\hline \multicolumn{5}{|l|}{ Estonia } \\
\hline $\ln$ (output) & 2.5790 & 0.6434 & 0.0406 & $71.4 \%$ \\
\hline$p$ values & 0.025 & 0.002 & 0.573 & \\
\hline \multicolumn{5}{|l|}{ Lithuania } \\
\hline $\ln$ (output) & 0.45909 & 0.4158 & 0.1199 & $61.0 \%$ \\
\hline$p$ values & 0.005 & 0.067 & 0.199 & \\
\hline
\end{tabular}

In the equation presented above there are results shown for a simple model to display relationships between GDP and loans for the case of Latvia. The $R^{2}$ for this model is $77 \%$. Similarly, the models for Estonia and Lithuania also explain the relatively high level of variance (71\% and $61 \%)$. The connection between loans and GDP is positive. In Latvia, if loans increase by $1 \%$, GDP in the next period will increase by $0.03 \%$, in Estonia GDP in next period will increase by $0.04 \%$, but in Lithuania even by $0.12 \%$. However, these coefficients are not significant, so further research at a more disaggregated level is needed to test the relations between several sectors of economy and loans influencing them. That is why the authors will test similar models also for construction, wholesale/retail and operations with real estate.

Different sectors of economy strongly interact with each other so to perform a similar analysis at the disaggregated level, it is also necessary to consider the need to include the values from other sector output or loans as explanatory variables. In this paper the authors have looked at the sectors of economy just at an overview level using simple models for understanding the main trends. Attachment 2 provides results for the model estimated for specific sectors. There are included coefficients, as well as the $\mathrm{p}$ values showing the coefficient significance levels and coefficients of determination.

First of all, the model for the construction sector shows that in Latvia if the loans for construction increase by $1 \%$, in the next period the output of construction will increase by approximately $0.1 \%$, in Estonia it decrease by $0.08 \%$, in Lithuania - increase by $0.18 \%$, but we should keep in mind that the previous tests for the construction sector showed that loans and output in the sector are not strongly connected. That can also be seen in the coefficient of determination which for this model is low. The operations with real estate show more significant results. The model for this sector in each country explains around $88 \%$ of the variance. If the loans for the operations with real estate increase by $1 \%$, the output of this sector in the next period will increase by $0.1 \%$ in Latvia, $0.1 \%$ in Estonia and $0.01 \%$ in Lithuania. But also for this model the coefficient showing the relationships between the loans and output is not significant (similarly as for the economy as a whole and other sectors examined).

Similarly, the third sectorial model examined (for wholesale and retail) despite having a quite high coefficient of determination (from $60 \%$ to $70 \%$ ), does not either present a significant coefficient for the variable showing loan-output relationships. Moreover, in this case the coefficient is negative meaning that loans for the wholesale and retail industry would decrease the output of this sector in next period which are not the results that could have been logically expected and the authors conclude that, though there are some relationships between loans and output both in the economy as a whole as well as particular industries, there are also other significant factors that influence the results. One factor that was not included in this simplified overview but could have a significant effect, especially in industries looking at the quarterly data is seasonality as the output (for example, in construction) can be much more influenced by season, although the loans available may help this industry prosper. It is also possible that a longer period of time is needed to use the loans and apply them to get the return from the products or services sold (for example, if construction projects are longer than one quarter). 


\section{Conclusions}

Analysis of Baltic States' GDPs and loan indices (the changes in the credit granting volume over the previous year), showed a positive growth until year 2007 (inclusive) and this ratio correlated with changes of GDP, whereas in 2008 the Credit granting volumes continued to grow, despite the fall of real GDP. Based on empirical research, the leading factor between the two variables - GDP and Lending is GDP, because the changes in the lending follow the changes in GDP. Accordingly, the authors conclude that in Baltic States lending will restart only when Baltic States economy shows growth in some consecutive quarters, not vice versa - the renewal of lending will lead to the GDP growth.

Having tested the causality between the loans and output in the Baltic States by exploiting the Granger causality test (using 2005-2010 quarterly dataset), the authors conclude that there is a controversy in the results and some industries support the hypothesis, but others do not. The results can diverse even in the same industries between the countries. This means that the constructed model does not include all the factors, which might impact the model performance.

The largest effect of the connection between the loans and output are in wholesale and retail sector where the causality observed is in both directions both in Latvia and Estonia. The loans available to the operations with real estate influence the output in this sector. The loans for this sector should be issued with caution and after a careful examination of the economic situation and possibilities of further development as the recent experience in the Baltic countries showed that exaggerated crediting of the operations with real sector was one of the factors leading to the economic downturn of year 2009.

The output of agriculture has influenced the value of outstanding loans to agriculture in Lithuania and Estonia, but no causality for this sector was found in Latvia. Similarly, also the manufacturing output influences the value of the outstanding loans to manufacturing sector in Latvia and Estonia, but the connection is shown to be weaker in Lithuania.

The results show that both GDP and the amount of the outstanding loans depend strongly on their value in the previous quarter because the partial correlation with lag 1 features a spike, but the autocorrelation values decrease and this decrease is close to an exponential decrease.

Based on the information that the GDP value depends on its value in the previous period the econometric model showing the loan impact on GDP was built. This model shows that the increase of loans by $1 \%$ raises the GDP value by $0.03 \%$ in Latvia, $0.12 \%$ in Lithuania, however decreases it by $0.04 \%$ in Estonia, although these coefficients are not statistically significant. Additional analysis was performed at a more disaggregated level examining if these relationships are also relevant at the particular industry level.

Both in construction and operations with real estate if the loans available increase, the models also show an increase in the output of these sectors (though the coefficients are not statistically significant). In the wholesale and retail sector the model presents a controversial result - in this case the coefficient is negative meaning that the loans for the wholesale and retail industry would decrease the output of this sector in next period which are not the results that could be logically explained.

The availability of credit resources is essential for successful growth of companies, industries and overall GDP, but the industries with a better development pace have better access to credit resources.

\section{References}

Ashcraft, A. (2006). New evidence on the lending channel. Journal of Money, Credit and Banking, Vol. 38(3), p. 751761.

Bebczuk, R., Burdisso, T., Carrera, J., Sangiácomo M. (2010). A new look into credit procyclicality: International panel evidence. BIS CCA Conference proceedings. Buenos Aires, 18-19 March, p. 122-169.

Beck, T., Levine, R., Loayza, N. (2000). Finance and the sources of growth. Journal of Financial Economics, Vol. 58, p. 261-300. 
Bernanke, B. S. (1983). Nonmonetary effects of the financial crisis in the propagation of the great depression. American Economic Review, Vol. 73 (2), p. 257-276.

Braslins, G., Orlovs, A., Brauksa, I. (2012). Industries leverage and Structural Development of Baltic States Economies. Proceedings of the International Conference "Trends in Economics and Management for the $21^{\text {st }}$ Century", Brno, p. 182-190.

Brunner, K., Meltzer, A. H. (1963). The place of financial intermediaries in the transmission of monetary policy. American Economic Review, Vol. 53 (2), p. 372-382.

Brunner, A., Gray, G., Miyajima, K., Prokopenko, V. (2006). IMF, Republic of Latvia, Selected Issues, September 19.

Canoy, M., Lerais, F. (2007). Beyond GDP: Overview paper for the Beyond GDP conference. Bureau of European Policy Advisers (BEPA), European Commission.

Cappiello, L., Kadareja, A., Sørensen, Ch. K., Protopapa, M. (2010). Do Bank Loans and Credit standards have an Effect on Output. European central bank working papers, No. 1150 / January 2010, 28 p.

Driscoll, J. C. (2004). Does bank lending affect output? Evidence from the U.S. states. Journal of Monetary Economics, Vol. 51, p. 451-471.

Erbenova, M., Liu, Y., Saxegaard, M. (2011). Corporate and Household Debt Distress in Latvia: Strengthening the Incentives for Market-Based Approach to Debt Resolution, IMF Working Paper.

Favara, G. (2003). An Empirical Reassessment of the Relationship between Finance and Growth. IMF Working Paper, Vol. 03(123).

Gambacorta, L., Mistrulli, P. E. (2005). Bank capital and lending behaviour: empirical evidence for Italy. Journal of Monetary Economics, Vol. 51, p. 431-439.

Gertler, M., Gilchrist, S. (1994). Monetary policy, business cycles and the behaviour of small manufacturing firms. Quarterly Journal of Economics, Vol. 109 (2), p. 309-340.

Miron, J., Romer, C. D., Weil, D. (1994). Historical perspectives on the monetary transmission mechanism. In: N. G. Mankiw (ed.). Monetary Policy. Chicago, IL: University of Chicago Press.

Oliner, S. D., Rudebusch, G. D. (1996). Is there a broad credit channel for monetary policy? Federal Reserve Bank of San Francisco Economic Review, Vol. 1, p. 300-309.

Romānova, I. (2006). The Role of Commercial Banks Loans in the Long-term Development of Economy. Rīga: Latvijas Universitāte, Ekonomikas un vadības fakultāte.

Sendeniz-Yuncu, I., Akdeniz, L., Aydogan, K. (2008). Interdependence of the banking sector and the real sector: evidence from OECD countries. Applied Economics, Vol. 40 (6), p. 749-764.

Shan, J., Jianhong, Q. (2006). Does financial development lead economic growth? The case of China. Annals of Economics and Finance, Vol. 1, p. 231-250.

Schumpeter, J. (1934). The Theory of Economic Development, Translated by Redvers Opie. Cambridge, MA, Harvard University Press.

Tecles, P. L., Tabak, B. M. (2008). Estimating the credit - GDP elasticity: the case of Brazil. The Banco Central do Brasil Working, No. 229.

\section{BVP IR SKOLINIMO ELGSENA：EMPIRINIAI BALTIJOS ŠALIU EKONOMIKOS POŽYMIAI}

Ģirts Braslinš̌, Aleksis Orlovs, Ieva Braukša, Aldis Bulis

Latvijos universitetas (Latvija)

Santrauka

Darnus ekonominis vystymasis remiasi stabilia ir palankia verslo aplinka, kuri skatina organizaciju konkurencingumą. Komerciniai bankai palengvina kapitalo judejimą iš mažiau efektyvių ekonomikos sektoriu i labiau konkurencingas ekonomikos šakas. Šio tyrimo tikslas - išanalizuoti Baltijos šalių BVP dinamiką 2005-2010 metais ir patikrinti BVP koreliavimą su vietinių komercinių bankų išduotu paskolu verslui skaičiumi. Tyrimo rezultatai parodè, kad yra požymių, jog egzistuoja abipusė priklausomybė tarp BVP veiksnių ir išduotų paskolų, tai savo ruožtu sudaro pagrindą formuoti pasiūlymus, kaip gaivinti 
Baltijos šalių ekonomiką. Šešiose pramonès šakose atliktas Granger BVP ir skolinimo priežastingumo testas pateikè prieštaringų rezultatų ir parodė, kad išeiga kai kuriose pramonès šakose turi abipusi ryši su finansinių išteklių prieinamumu, tačiau verslo šakos vystymasis lemia tai, kad suteikiama daugiau paskolų, taip užtikrinama tolesnè sektoriaus plètra. Tyrime taikyti sisteminès, loginès ir lyginamosios bei statistinès analizès, ekspertiniai metodai, apibendrinimas ir ekonometrinis Granger priežastingumo testo metodas.

PAGRINDINIAI ŽODŽIAI: paskolos, BVP, Granger priežastingumo testas, paskolos ir išeiga.

JEL KLASIFIKACIJA: E32, G10. 
Attachment 1

Table 3. Results of Granger test for all three Baltic countries split by sectors: Wholesale, Transport and Operations with real estate

\begin{tabular}{|c|c|c|c|}
\hline & \multicolumn{3}{|c|}{ Probabilities $^{5}$} \\
\hline Null Hypothesis: & Latvia & Estonia & Lithuania \\
\hline \multicolumn{4}{|l|}{ Wholesale/Retail ${ }^{6}$ : } \\
\hline LOAN_SALES does not Granger Cause OUT_SALES & 0.0102 & 0.0177 & 0.1723 \\
\hline OUT_SALES does not Granger Cause LOAN_SALES & 0.0013 & 0.0455 & 0.9692 \\
\hline GDP does not Granger Cause LOAN_SALES & 0.0105 & 0.0034 & 0.2269 \\
\hline LOAN_SALES does not Granger Cause GDP & 0.1598 & 0.0803 & 0.0556 \\
\hline \multicolumn{4}{|l|}{ Transport/Logistics: } \\
\hline LOAN_TRANSPORT does not Granger Cause OUT_TRANSPORT & 0.3951 & 0.5522 & 0.1723 \\
\hline OUT_TRANSPORT does not Granger Cause LOAN_TRANSPORT & 0.2417 & 0.2016 & 0.9692 \\
\hline GDP does not Granger Cause LOAN_TRANSPORT & 0.008 & 0.3222 & 0.2269 \\
\hline LOAN_TRANSPORT does not Granger Cause GDP & 0.0189 & 0.31 & 0.0556 \\
\hline \multicolumn{4}{|l|}{ Operations with real estate: } \\
\hline LOAN_REAL_ESTATE does not Granger Cause OUT_REAL_ESTATE & 0.0126 & 0.0394 & 0.0387 \\
\hline OUT_REAL_ESTATE does not Granger Cause LOAN_REAL_ESTATE & 0.4499 & 0.5988 & 0.4082 \\
\hline GDP does not Granger Cause LOAN_REAL_ESTATE & 0.8115 & 0.4023 & 0.1398 \\
\hline LOAN_REAL_ESTATE does not Granger Cause GDP & 0.4407 & 0.2523 & 0.0178 \\
\hline \multicolumn{4}{|l|}{ Agriculture: } \\
\hline LOAN_AGRICULTURE does not Granger Cause OUT_AGRICULTURE & 0.9196 & 0.7407 & 0,1452 \\
\hline OUT_AGRICULTURE does not Granger Cause LOAN_AGRICULTURE & 0.8647 & 0,0042 & 0.0629 \\
\hline GDP does not Granger Cause LOAN_AGRICULTURE & 0,5338 & 0.0448 & 0,002 \\
\hline LOAN_AGRICULTURE does not Granger Cause GDP & 0.0787 & 0,0683 & 0.0021 \\
\hline \multicolumn{4}{|l|}{ Manufacture: } \\
\hline LOAN_MANIFACTURE does not Granger Cause OUT_MANIFACTURE & 0.6522 & 0.1899 & 0,7615 \\
\hline OUT_MANIFACTURE does not Granger Cause LOAN_MANIFACTURE & 0.0845 & 0.0098 & 0.1264 \\
\hline GDP does not Granger Cause LOAN_MANIFACTURE & 0.1601 & 0.0014 & 0.0646 \\
\hline LOAN_MANIFACTURE does not Granger Cause GDP & 0.1773 & 0.0407 & 0.0758 \\
\hline \multicolumn{4}{|l|}{ Construction: } \\
\hline LOAN_CONSTRUCTION does not Granger Cause OUT_CONSTRUCTION & 0.1209 & 0.0191 & 0.0826 \\
\hline OUT_CONSTRUCTION does not Granger Cause LOAN_CONSTRUCTION & 0.3852 & 0.2074 & 0.3 \\
\hline GDP does not Granger Cause LOAN_CONSTRUCTION & 0.3641 & 0.1759 & 0.4784 \\
\hline LOAN_CONSTRUCTION does not Granger Cause GDP & 0.8607 & 0.127 & 0.2344 \\
\hline
\end{tabular}

5 If probability $<0.05$, null hypothesis is rejected with $95 \%$ confidence.

6 For Lithuania Wholesale/Retail sector data are combined with Transport/Logistics and Accomodation sectors. 
Attachment 2

Table 4. Results of model estimates for specific sectors for Latvia

\begin{tabular}{|c|c|c|c|c|}
\hline In_out ${ }_{\mathrm{i}}(\text { Output in sector } i)^{7}$ & constant & In_out $(t-1)$ & $\ln \_\operatorname{loan}_{i}(\mathrm{t}-1)$ & $R^{2}$ \\
\hline Construction & 5.374 & 0.464 & 0.095 & $34.6 \%$ \\
\hline$p$ values & $(0.044)$ & $(0.030)$ & $(0.678)$ & \\
\hline Real estate & 3.147 & 0.618 & 0.111 & $88.0 \%$ \\
\hline$p$ values & $(0.018)$ & $(0.005)$ & $(0.257)$ & \\
\hline Wholesale and retail & 3.918 & 0.851 & -0.144 & $72.8 \%$ \\
\hline$p$ values & $(0.013)$ & $(0.000)$ & $(0.163)$ & \\
\hline
\end{tabular}

Source: Data from the Central Statistical Bureau of the Republic of Latvia and the Financial and Capital Market Commission of Latvia, authors' estimates

Table 5. Results of model estimates for specific sectors for Estonia

\begin{tabular}{|l|l|l|l|l|}
\hline In_out & (Output in sector $\boldsymbol{i})$ & constant & $\ln \_$out $_{i}(\boldsymbol{t}-\mathbf{1})$ & $\ln \_$loan \\
$\boldsymbol{i}$ & $(\boldsymbol{t}-\mathbf{1})$ & $\boldsymbol{R}^{\mathbf{2}}$ \\
\hline Construction & 2.146 & 0.695 & -0.08 & $49.8 \%$ \\
\hline$p$ values & $(0.026)$ & $(0.000)$ & $(0.312)$ & \\
\hline Real estate & 1.845 & 0.553 & 0.099 & $86.2 \%$ \\
\hline$p$ values & $(0.016)$ & $(0.009)$ & $(0.130)$ & \\
\hline Wholesale and retail & 1.662 & 0.744 & -0.017 & $59.3 \%$ \\
\hline$p$ values & $(0.054)$ & $(0.000)$ & $(0.858)$ & \\
\hline
\end{tabular}

Source: Data from the Statistics Estonia, the Eesti Pank, authors' estimates

Table 6. Results of model estimates for specific sectors for Lithuania

\begin{tabular}{|c|c|c|c|c|}
\hline In_out ${ }_{i}(\text { Output in sector } i)^{8}$ & constant & $\ln \_$out $(t-1)$ & $\ln \_\operatorname{loan}_{i}(t-1)$ & $R^{2}$ \\
\hline Construction & 3.119 & $0 . \overline{406}$ & $0 . \overline{175}$ & $33.9 \%$ \\
\hline$p$ values & $(0.039)$ & $(0.088)$ & $(0.472)$ & \\
\hline Real estate & 1.8152 & 0.836 & 0.006 & $88.5 \%$ \\
\hline$p$ values & $(0.178)$ & $(0.000)$ & $(0.909)$ & \\
\hline Wholesale and retail & 3.326 & 0.401 & 0.213 & $70.5 \%$ \\
\hline$p$ values & $(0.004)$ & $(0.071)$ & $(0.106)$ & \\
\hline
\end{tabular}

Source: Data from the Statistics Lithuania and the Bank of Lithuania, authors' estimates

\footnotetext{
Note: $\mathrm{i}$ - variable dependent on sector
}

8 Note: i - variable dependent on sector 